\title{
Urgences
}

\section{Retour à Miguasha}

\section{Renaud Longchamps}

Numéro 33, octobre 1991

Poésies parallèles : France - Québec

URI : https://id.erudit.org/iderudit/025662ar

DOI : https://doi.org/10.7202/025662ar

Aller au sommaire du numéro

Éditeur(s)

Urgences

ISSN

0226-9554 (imprimé)

1927-3924 (numérique)

Découvrir la revue

Citer ce document

Longchamps, R. (1991). Retour à Miguasha. Urgences, (33).

https://doi.org/10.7202/025662ar d'utilisation que vous pouvez consulter en ligne.

https://apropos.erudit.org/fr/usagers/politique-dutilisation/ 


\title{
Retour à Miguasha
}

\section{Renaud Longchamps}

\author{
Vous vivez \\ et l'océan n'agite plus \\ sa surface \\ aveugle des soulèvements \\ Plus tard \\ vous verrez aux continents temporaires \\ contre lesquels se briseront \\ à l'aurore \\ les futurs ancêtres \\ Le renoncement viendra avec le sommeil \\ et les dépôts erratiques \\ nécessaires \\ au départ \\ Le renoncement amorce \\ lagonie \\ L'oubli \\ et le témoignage de l'oubli
}


36

Jai vu

la vieille terre

s'effriter

dans la nuit et le vide impérial

Elle ressemblait aux planètes perdues,

à l'espèce

inachevée

Je combattais alors la gravité et l'horizon, ce qui ploie sous la géométrie

quand elle broie la matière

Maintenant vous rampez pour un territoire qui s'use à vous parler

les langues inutiles

à l'amour

Contrairement aux cailloux

ici-bas rebattus

sous l'océan

des effondrements 
Le ciel se ferme

sur la dernière naissance

Tu vis par le gène

à ton pied

à ton œil

Il brisera la chaîne

il forgera la chaîne

il cherchera l'univers dans un dé

L'univers se referme

sur les mots de la naissance

Il cherche l'espace

derrière le temps 
38

Où est le temps de la première mort?

L'ordre naît du chaos

et je parle d'une matière inquiète de son silence

Voilà l'anomalie voilà la naissance

Elle viendra éconduire le cerveau hors de l'humanité cérébelleuse

C'est la fin et le singe au creux de ma main persiste, signe

Plus tard il écrira sur Lascaux

C'est la fin

et la vieille intelligence fermera l'étoile à la mémoire 
Vous occupez le temps

que vous ne comprenez pas

Je perds le hasard

de dire le dernier mensonge

Il sera demain

pour la vieille intelligence

qui refuse notre futur

Qui sait

s'il n'est pas sacrifice

du premier carnassier

Je m'adresse à celle

dont l'intuition ne fait pas l'ombre d'un doute

Je m'adresse à la désemparée 